\title{
Distribution of prokaryotic picophytoplankton from Seto Inland Sea to the Kuroshio region, with special reference to 'Kyucho' events
}

\author{
Toshiya Katano ${ }^{1,2, *}$, Atsushi Kaneda ${ }^{1}$, Naoto Kanzaki ${ }^{3}$, Yumiko Obayashi ${ }^{1}$, \\ Akihiko Morimoto ${ }^{4}$, Goh Onitsuka ${ }^{5}$, Hideichi Yasuda ${ }^{5}$, Sotaro Mizutani ${ }^{6}$, \\ Yoshihide Kon $^{6}$, Kazuhiro Hata ${ }^{6}$, Hidetaka Takeoka ${ }^{1}$, Shin-ichi Nakano ${ }^{3}$ \\ ${ }^{1}$ Center for Marine Environmental Studies, Ehime University, Bunkyo-cho 3, Matsuyama 790-8577, Japan \\ ${ }^{2}$ Department of Life Science, Hanyang University, Seoul 133-791, Korea \\ ${ }^{3}$ Faculty of Agriculture, Ehime University, Tarumi 3-5-7, Matsuyama 790-8566, Japan \\ ${ }^{4}$ Hydrospheric Atmospheric Research Center, Nagoya University, Nagoya 464-8601, Japan \\ ${ }^{5}$ Department of Fisheries Information and Management, and ${ }^{6} \mathrm{TV}$ 'Tenyo-maru', National Fisheries University, \\ Shimonoseki 759-6595, Japan
}

\begin{abstract}
A 'Kyucho' (an intrusion of warm surface water) occurs in the Bungo Channel, located in southwestern Japan. The abundances of Prochlorococcus and Synechococcus during a Kyucho, together with physical and chemical environmental factors, were investigated from the Kuroshio region to the Seto Inland Sea, via Bungo Channel, from 26 November to 5 December 2003. With the occurrence of the Kyucho, oceanic water intruded from the Kuroshio region into the middle of the Bungo Channel. The abundance of Prochlorococcus was the highest in the Kuroshio region and the southern part of the Bungo Channel $\left(>25 \times 10^{3} \mathrm{cells} \mathrm{ml}^{-1}\right)$, low in the northern part of the Bungo Channel $\left(<1 \times 10^{3}\right.$ cells $\left.\mathrm{ml}^{-1}\right)$, and below detection levels in the Seto Inland Sea. A relatively high abundance of Synechococcus cells $\left(>15 \times 10^{3}\right.$ cells $\left.\mathrm{ml}^{-1}\right)$ was detected in the Kuroshio region and in the southern part of the Bungo Channel, but the abundance $\left(<6 \times 10^{3}\right.$ cells $\left.\mathrm{ml}^{-1}\right)$ was low in other regions. In the Kuroshio region and the southern part of the Bungo Channel, high-phycourobilin (PUB)-type cells were dominant $(>90 \%)$; at this location, most of the available light in the deeper layer (>25 m depth) was in the 450 to $500 \mathrm{~nm}$ range, corresponding to the peak absorbance of PUB. In contrast, the abundance of low-PUB-type cells accounted for $>75 \%$ of the total in the northern part of the Bungo Channel and in the Seto Inland Sea, where most of the available light in the deeper layer (>10 m depth) was in the 480 to $560 \mathrm{~nm}$ range, including the peak absorbance of both PUB and phycoerythrobilin (PEB). These results indicate that Synechococcus cells of high-PUB type, which have a higher Ex 495:545 (>1.5; ratio of orange fluorescence intensity excited at $495 \mathrm{~nm}$ to that at 545 $\mathrm{nm})$, as well as Prochlorococcus cells were advected to the Bungo Channel by the Kyucho. The cooccurrence of the 2 pigment types of Synechococcus in coastal waters is highly affected by a physical process, such as the Kyucho.
\end{abstract}

KEY WORDS: Prochlorococcus $\cdot$ Synechococcus $\cdot$ Kyucho $\cdot$ Kuroshio $\cdot$ Phycoerythrin $\cdot$ Pigment type Advection $\cdot$ Dual laser flow cytometry $\cdot$ Spectrofluorometry

\section{INTRODUCTION}

Prochlorococcus and Synechococcus, taxa of the prokaryotic picophytoplankton, are responsible for a significant proportion of primary production in marine environments (Agawin et al. 2000, Bell \& Kalff 2001).
The cells of both Prochlorococcus and Synechococcus have been enumerated by flow cytometry in various marine environments (e.g. Li 1995). Prochlorococcus, which is the smallest oxygenic photoautotroph (ca. 0.5 to $0.6 \mu \mathrm{m}$ in diameter), is numerically abundant $\left(10^{5}\right.$ cells $\left.\mathrm{ml}^{-1}\right)$, especially in the tropical ocean (Parten- 
sky et al. 1999), and its distribution is generally restricted in the open ocean (Partensky et al. 1999). Synechococcus, which is large (ca. $1 \mu \mathrm{m}$ in diameter) relative to Prochlorococcus, is ubiquitously distributed from the open ocean to the coastal sea (e.g. Olson et al. 1990). The composition of prokaryotic picophytoplankton is variable in every ocean and coastal sea.

Most marine Synechococcus cells possess phycoerythrin (PE) as a major light-harvesting pigment (Alberte et al. 1984, Ong et al. 1984). PE in the cell contains both phycoerythrobilin (PEB) and phycourobilin (PUB) or PEB alone. The peak wavelengths of absorption for PUB and PEB are 495 and $545 \mathrm{~nm}$, respectively (Ong et al. 1984). The chromophore compositions of PUB and PEB are highly variable among isolated strains (Wood et al. 1985, Waterbury et al. 1986, Toledo et al. 1999, Palenik 2001, Rocap et al. 2002, Fuller et al. 2003). Since 495 and $545 \mathrm{~nm}$ of light are dominant in natural seawater, the ratio of PUB:PEB is important in order to harvest light in natural environments.

Spectrofluorometry has been used to evaluate the relative content of PUB and PEB in isolated strains (Toledo et al. 1999, Palenik 2001, Fuller et al. 2003), although it cannot determine the real amount of the these chromophores. In the analysis, the ratio of orange fluorescence intensity excited at $495 \mathrm{~nm}$ to that at $545 \mathrm{~nm}$ (Ex 495:545) is used as the index of PUB and PEB in PE. The index has also been applied to natural seawater (Lantoine \& Neveux 1997, Wood et al. 1998, 1999). The Ex 495:545 of PE in oligotrophic oceans was ca. 2.0; this was almost the highest value found anywhere (Lantoine \& Neveux 1997). Similar results were obtained in the Arabian Sea (Wood et al. 1999). However, since spectrofluorometry measures the fluorescence from the overall PE in the sample, the data did not indicate the PUB:PEB ratio for each Synechococcus cell. Dual laser flow cytometry, which was first used by Olson et al. (1988), is a powerful tool for the analysis of the PUB:PEB ratio for each Synechococcus cell in natural seawater. In addition, the Ex 495:545 of Synechococcus cells can be analyzed by spectrofluorometry after cell sorting.

In the Bungo Channel, located in southwestern Japan, an intermittent physical event occurs called the 'Kyu$c h o^{\prime}$. This sudden and swift current is usually accompanied by an increase in the water temperature (Takeoka et al. 2000) caused by an intrusion of warm water originating from the Kuroshio region into the eastern half of the Bungo Channel (Akiyama \& Saitoh 1993) that is driven gravitationally and advances along the eastern coast of the channel (Takeoka et al. 1993). Thus, it is possible that the Kyucho transports picophytoplankton from the Kuroshio region to the Bungo Channel.

Recently, we reported on the abundance of Prochlorococcus in a bay on the Bungo Channel (Katano et al. 2005). We were also able to determine that Syne- chococcus in the bay consisted of a different type of PUB:PEB cells (Katano et al. 2004, Katano \& Nakano 2006). The composition of these 2 types significantly fluctuated during the summer season, when the Kyucho frequently occurs (Katano et al. 2004). Thus, this fluctuation appears to be related to the occurrence of the Kyucho. However, the abundances of Prochlorococcus and Synechococcus during the Kyucho and in the Kuroshio region have not yet been investigated.

In the present study, we investigated the abundances of Prochlorococcus and Synechococcus from the Kuroshio region to the Seto Inland Sea during the Kyucho. Synechococcus cells were classified on the basis of their PUB:PEB ratio, and cell densities were separately enumerated using a dual laser flow cytometer. Ex 495:545 of these classified Synechococcus cells were analyzed by spectrofluorometry after cell sorting. The underwater light environment and other physical and chemical factors were also investigated.

\section{MATERIALS AND METHODS}

Monitoring the Kyucho. To monitor the Kyucho, the water temperature was measured every 30 min with a thermistor at a depth of $5 \mathrm{~m}$ at 8 stations located in the eastern part of the Bungo Channel, Japan (Fig. 1).

Sampling. This study was conducted during a research cruise from 26 November to 5 December 2003 on the TV 'Tenyo-maru' (Fig. 1). The water temperature and salinity were measured with a CTD (conductivity, temperature, depth) profiler (SBE9plus, SeaBird), and water samples were collected with Niskin bottles mounted on a rosette to determine the nutrient and chlorophyll $a(\mathrm{chl} a)$ concentrations. For the enumeration of prokaryotic picophytoplankton and analysis of the PE pigment of Synechococcus, water samples were vertically collected at Stns 2, 6, 13, 15, 20, and 43 (Fig. 1). In addition, to analyze the type of PE pigment of Synechococcus, a water sample was also collected at Stn 47 ; $5 \mathrm{ml}$ of each sample was fixed with glutaraldehyde at a final concentration of $0.1 \%$ and stored in liquid nitrogen during the cruise. The samples were stored in a $-80^{\circ} \mathrm{C}$ deep-freezer until flow cytometric analysis.

The light intensity was measured vertically with a spectroradiometer (LI-1800, Li-Cor) for each wavelength between 400 and $700 \mathrm{~nm}$ at Stns 6, 13, 15, and 43 (Fig. 1). The attenuation coefficients for photosynthetically available radiation (400 to $700 \mathrm{~nm}, K_{\mathrm{PAR}}$ ) were calculated. To compare the underwater light environment, the attenuation coefficients for 490 to $500 \mathrm{~nm}\left(K_{495}\right)$ and 540 to $550 \mathrm{~nm}\left(K_{545}\right)$ and the ratio of $K_{495}: K_{545}$ were also calculated.

Analysis of nutrient and chl a concentrations. Samples that were to be used to determine nutrient con- 

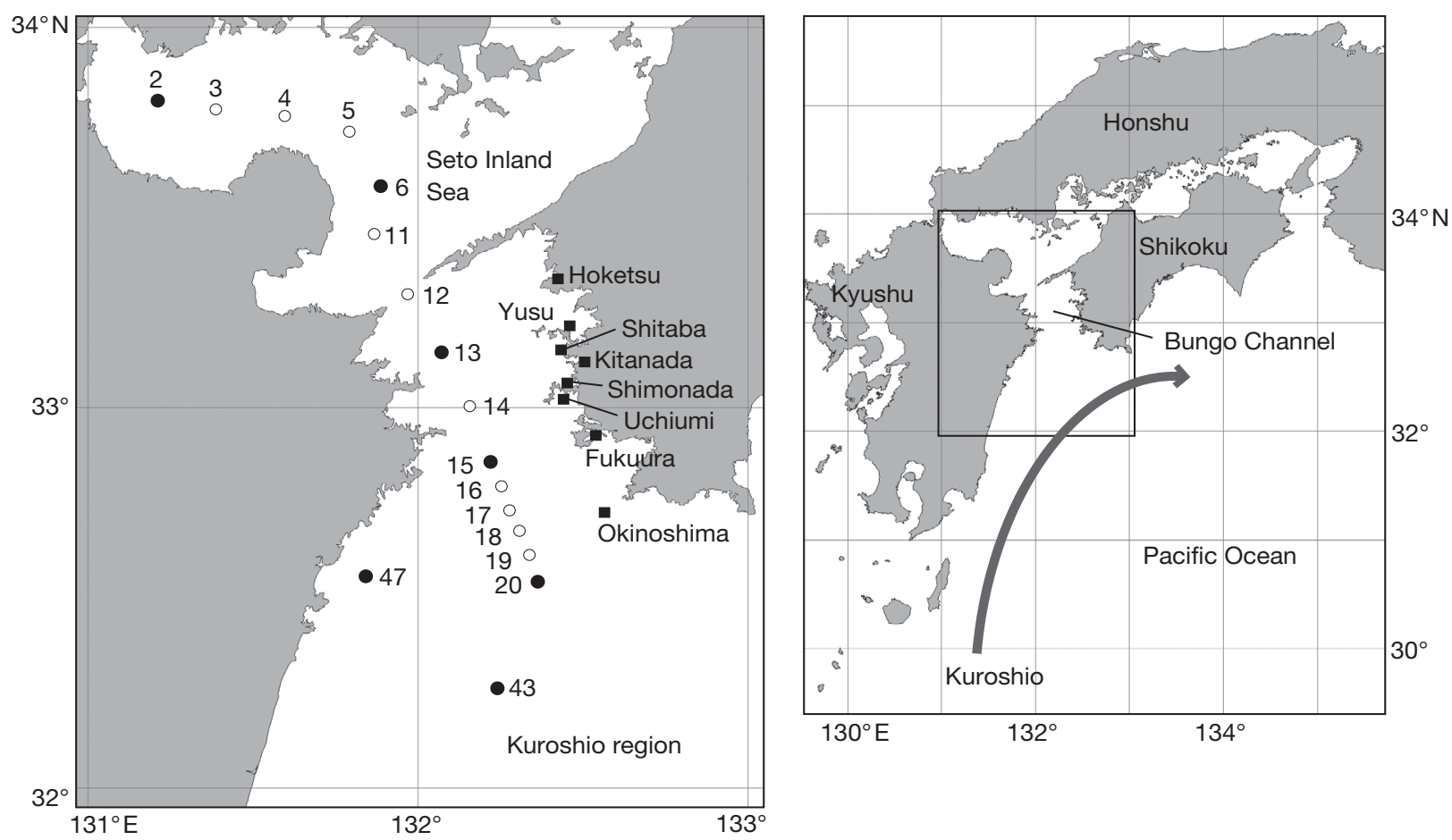

Fig. 1. Map of stations for conductivity, temperature, and depth (CTD) observations (O), CTD observations and flow cytometric analysis $(\bullet)$, and temperature measurement for Kyucho monitoring (ם)

centrations were filtered using syringe-top filters (pore size, $0.45 \mu \mathrm{m})$ to remove particles immediately after sampling. The samples were stored in a freezer $\left(-20^{\circ} \mathrm{C}\right)$ until analysis. The nitrate + nitrite, ammonium, and phosphate concentrations were measured with an autoanalyzer (AA3, BRAN + LUEBEE). To measure the chl a concentration, 500 to $1000 \mathrm{ml}$ of a seawater sample was filtered through a Nuclepore filter (pore size, $0.2 \mu \mathrm{m}$; Whatman). Thus, our chl a estimates include divinyl chl a in Prochlorococcus cells. Chl a on the filters was extracted with $\mathrm{N}, \mathrm{N}$-dimethylformamide (DMF), and its amounts were determined by acidification technique (Jeffrey \& Welschmeyer 1997) with a fluorometer (10-AU, Turner Designs).

Flow cytometry. The method for counting the Prochlorococcus and Synechococcus cells has been described previously (Katano et al. 2005, Katano \& Nakano 2006). The cell densities of Prochlorococcus and Synechococcus according to each type of pigment were counted with a flow cytometer (FACSvantage SE, Becton Dickinson) equipped with 2 water-cooled Argon lasers (INOVA305 and 306, Coherent): one (INOVA305) gives $488 \mathrm{~nm}$ of blue light, while the other (INOVA306) gives $514 \mathrm{~nm}$ of green light. Another portion of the water sample was filtered through a $0.1 \mu \mathrm{m}$ pore size membrane filter (Millipore), and the filtrate was used as the sheath fluid. Fluorescent beads $(2 \mu \mathrm{m}$, Polyscience) were also used as an internal standard for counting (Olson et al. 1993).
The forward scatter, side scatter, and 2 fluorescence intensities (FL2, orange, 564 to $586 \mathrm{~nm}$; FL3, red, 675 to $715 \mathrm{~nm}$ ) excited at $488 \mathrm{~nm}$ of light were recorded for each cell. The orange fluorescence intensity (FL4, 564 to $586 \mathrm{~nm}$ ) excited at $514 \mathrm{~nm}$ of light was also recorded. The forward and side scatters are related to the cell size and internal cell structure, respectively. The red fluorescence (FL3) indicates the cellular chlorophyll contents, and the orange (FL2) fluorescence is mainly related to the PUB contents of a Synechococcus cell. The orange fluorescence (FL4, excited at $514 \mathrm{~nm}$ ) is also related to the PUB + PEB contents of the cell. At an excitation of $514 \mathrm{~nm}, \mathrm{PUB}$ and PEB absorb almost equally, while, at an excitation of 488 nm, PUB absorbs more efficiently than PEB (Olson et al. 1988). Thus, the ratio of FL2:FL4 indicates the relative content of PUB:PEB of the Synechococcus cell. All parameters were normalized with $2 \mu \mathrm{m}$ fluorescent beads (Polyscience). To determine the relative content of PUB:PEB, the ratios of FL2:FL4 of the cells were calculated.

Spectrofluorometry. The fluorescence spectra of PE in sorted Synechococcus cells were analyzed with a scanning spectrofluorometer (F-2500, Hitachi). The fluorescence intensities were measured at $575 \mathrm{~nm}$ as well as the changes in excitation wavelength every $0.5 \mathrm{~nm}$ between 400 and $560 \mathrm{~nm}$. The band passes of the excitation and emission wavelengths were 10 and $5 \mathrm{~nm}$, respectively, and the scan speed was $1.5 \mathrm{~nm} \mathrm{~s}^{-1}$. 


\section{RESULTS}

\section{Kyucho occurrence}

An increase in water temperature at Fukuura, Uchiumi, Shimonada, Kitanada, and Shitaba indicated the occurrence of a Kyucho between 25 and 30 November 2003 (Fig. 2). The intrusion did not reach sites in the northern Bungo Channel, such as Hokestu and Yusu (Fig. 1). On 26 November, when the transect investigation was conducted, the oceanic water had intruded into Fukuura and Uchiumi, but had not yet reached Shimonada, Kitanada, and Shitaba.

\section{Transect investigation}

The water temperature was relatively low in the Seto Inland Sea $\left(<20^{\circ} \mathrm{C}\right)$ and the northern part of the Bungo Channel (20 to $21^{\circ} \mathrm{C}$; Fig. 3a). At Stn 15, the water temperature increased to $22^{\circ} \mathrm{C}$ because of the Kyucho (Fig. 3a). Salinity was also low in the Seto Inland Sea and increased in the Bungo Channel and the Kuroshio region (Fig. 3b). Nutrient concentrations in the Seto

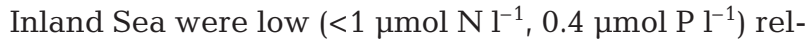
ative to those in the northern part of the Bungo Chan-

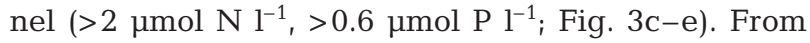
Stns 15 to 20, the nutrient concentrations were also low. The chl a concentration was high in the Seto Inland Sea $\left(>2 \mu \mathrm{g} \mathrm{l}^{-1}\right)$ and low in the Kuroshio region and in the southern part of Bungo Channel $\left(<0.5 \mu \mathrm{g} \mathrm{l}^{-1}\right.$;

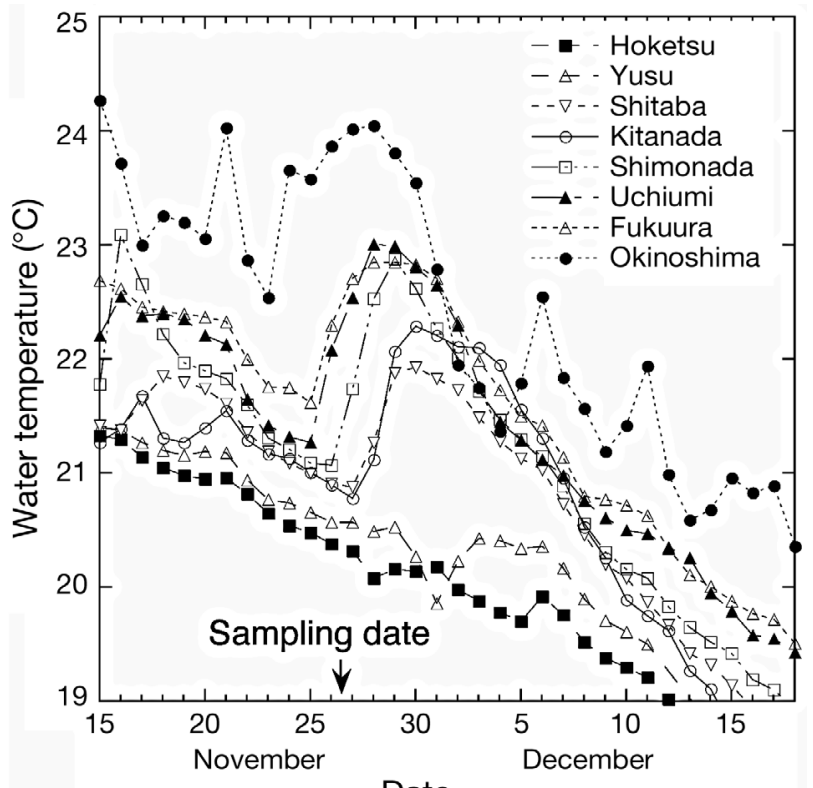

Date

Fig. 2. Changes in water temperature at stations located in the eastern part of the Bungo Channel during the study period. Data are mean values for $1 \mathrm{~d}$

Fig. 3f). Through the occurrence of the Kyucho, 3 regions were identified: the southern part of the Bungo Channel and the Kuroshio region, the northern part of the Bungo Channel, and the Seto Inland Sea. The ranges in water temperature and salinity in the 3 regions were $>21.4^{\circ} \mathrm{C}$ and $>34.3$ (the southern part of the Bungo Channel), 20.6 to $21.4^{\circ} \mathrm{C}$ and 33.9 to 34.3 (a) Water temperature $\left({ }^{\circ} \mathrm{C}\right)$
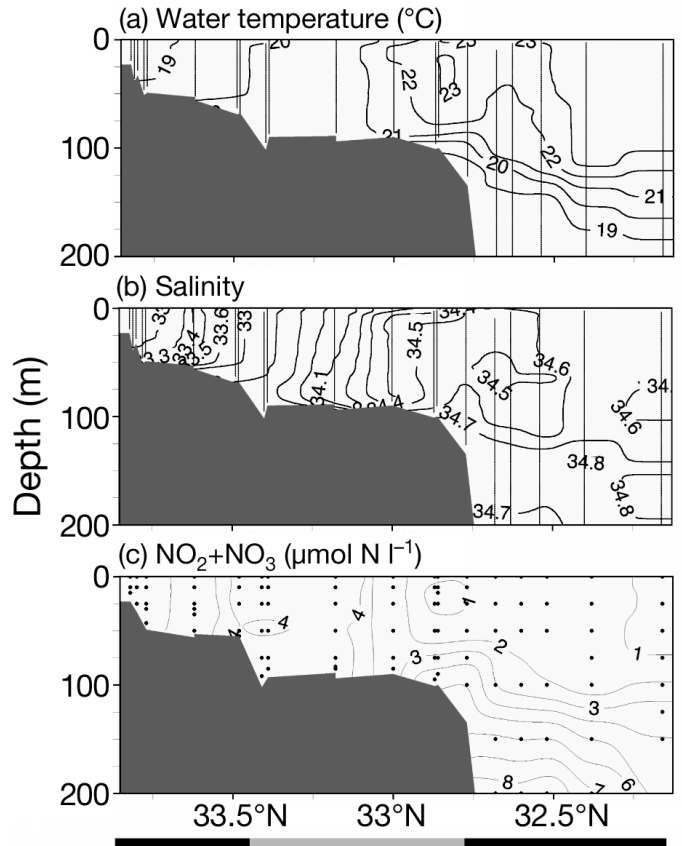

Seto Bungo Channel Kuroshio region Inland Sea (d) $\mathrm{NH}_{4}\left(\mu \mathrm{mol} \mathrm{N} \mathrm{I}{ }^{-1}\right)$

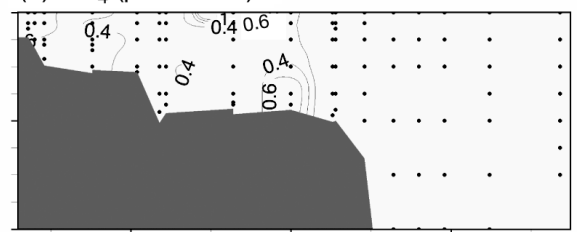

(e) $\mathrm{PO}_{4}\left(\mu \mathrm{mol} \mathrm{P} \mathrm{l}{ }^{-1}\right)$

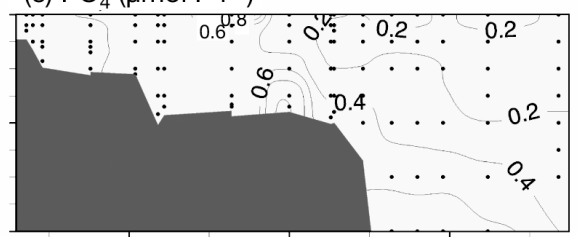

(f) Chlorophyll a $\left(\mathrm{gg} \mathrm{I}^{-1}\right)$

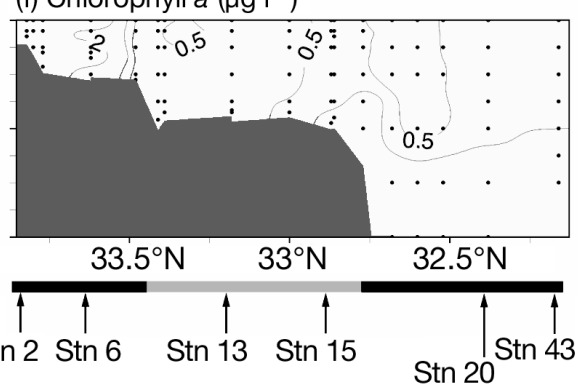

Fig. 3. Distributions of (a) water temperature, (b) salinity, (c) $\mathrm{NO}_{2}+\mathrm{NO}_{3}$, (d) $\mathrm{NH}_{4}$, (e) $\mathrm{PO}_{4}$, and (f) chlorophyll a concentrations from the Seto Inland Sea to the Kuroshio region. Horizontal axes indicate north-south transect from Stns 2 to 43. Lines in (a) and (b) show CTD casts. Dots in (c) to (f) show the depths and stations of the samples collected by Niskin water samplers 

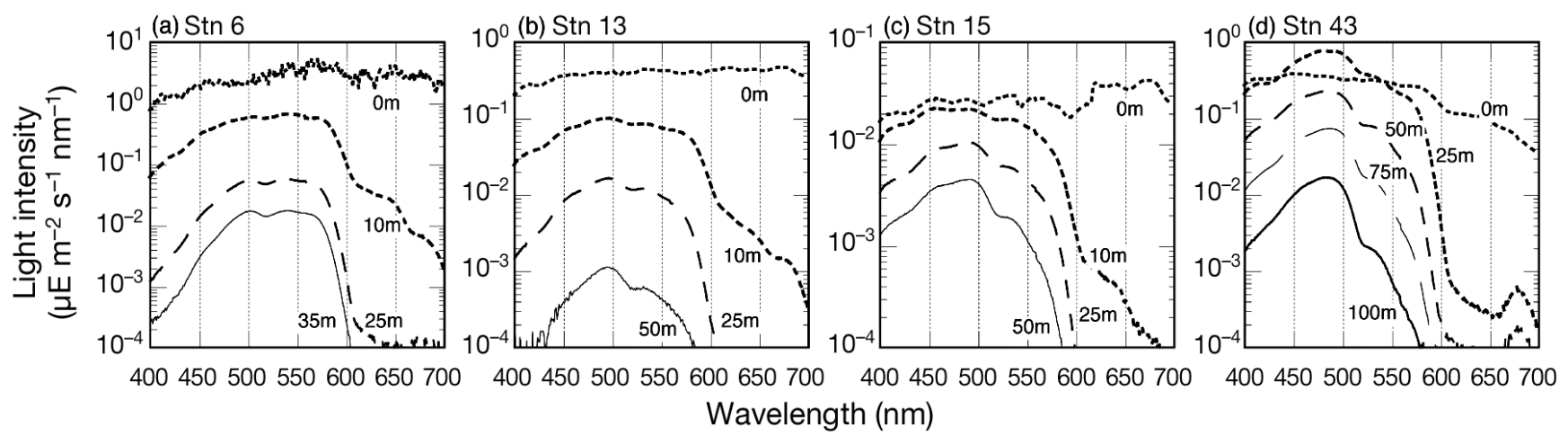

Fig. 4. Spectral distributions of downward irradiance in (a) the Seto Inland Sea, (b,c) the Bungo Channel, and (d) the Kuroshio Region

(the northern part of the Bungo Channel), and $<20.6^{\circ} \mathrm{C}$ and $<33.9$ (the Seto Inland Sea), respectively.

Most of the available light in the deeper layer $(25$ and/or $35 \mathrm{~m}$ depth) at Stns 6 and 13 for the growth of Synechococcus was in the 480 to $560 \mathrm{~nm}$ range (Fig. 4a,b). In contrast, the dominant light in the deeper layer (deeper than $25 \mathrm{~m}$ depth) at Stns 15 and 43 was

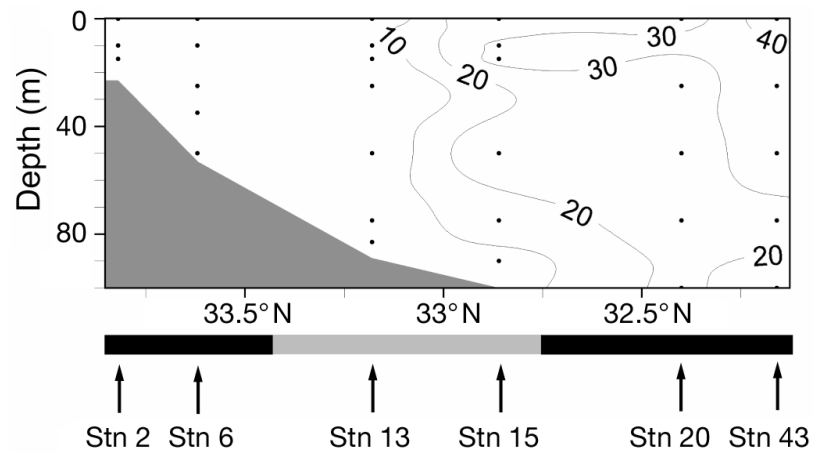

Fig. 5. Distribution of Prochlorococcus $\left(\times 10^{3}\right.$ cells ml $\left.{ }^{-1}\right)$ from the Seto Inland Sea to the Kuroshio region. Horizontal axis indicates north-south transect from Stns 2 to 43. Dots show the depths and stations of the samples collected by Niskin water samplers within the 450 to $500 \mathrm{~nm}$ range (Fig. $4 \mathrm{c}, \mathrm{d}$ ). The $K_{\mathrm{PAR}}$ was high at Stns 6 and $13\left(>0.15 \mathrm{~m}^{-1}\right.$; data not shown), but low at Stns 15 and $43\left(<0.07 \mathrm{~m}^{-1}\right)$. The $K_{495}: K_{545}$ was also high at Stns 6 and 13 (>0.86; data not shown), but low at Stns 15 and $43(<0.71)$.

\section{Distributions of Prochlorococcus and Synechococcus cells}

Prochlorococcus cells were not detected in the Seto Inland Sea (Stns 2 and 6; Fig. 5). In the northern part of the Bungo Channel, the cell densities of Prochlorococcus were low (Stn 13, <1 $\times 10^{3}$ cells ml $^{-1}$; Fig. 5). Interestingly, a relatively high abundance $\left(10 \times 10^{3}\right.$ to $47 \times$ $10^{3}$ cells $\mathrm{ml}^{-1}$ ) was observed in the Kuroshio region (Stns 20 and 43) and the southern part of the Bungo Channel, where oceanic water intruded (Stn 15). Cell distribution of Prochlorococcus was vertically uniform.

Two types of Synechococcus cells with different FL2:FL4 ratios were identified from the flow cytometric signatures (Fig. 6): one had a lower ratio of FL2:FL4 (the low-PUB type), while the other had a higher FL2:FL4 ratio (the high-PUB type). Cell densities of the (a) Stn $60 \mathrm{~m}$

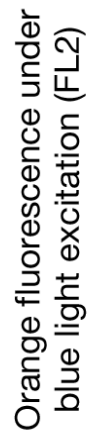

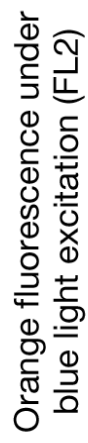

(b) Stn $130 \mathrm{~m}$

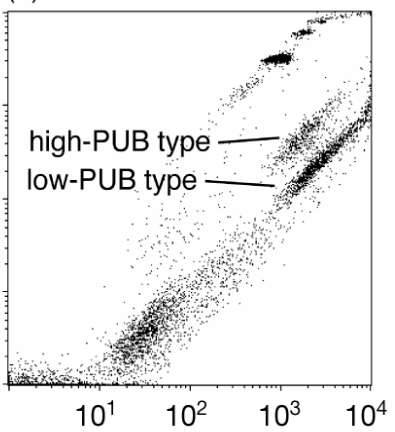

(c) Stn $150 \mathrm{~m}$

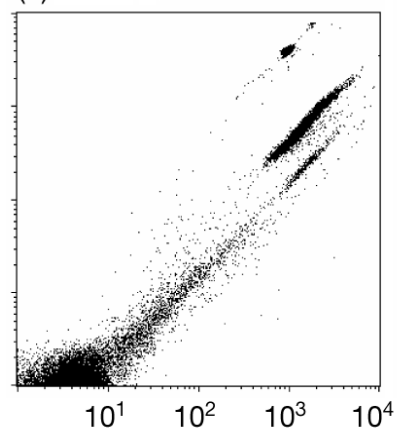

(d) Stn $430 \mathrm{~m}$

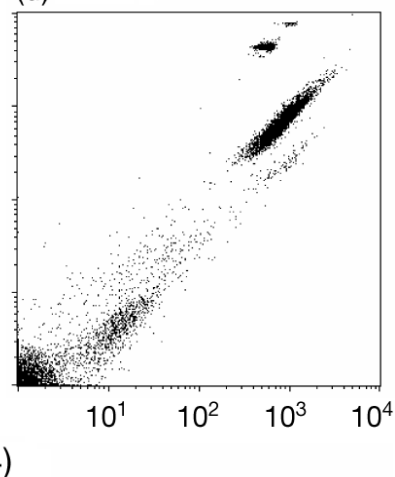

Orange fluorescence under green light excitation (FL4)

Fig. 6. Flow cytometric signatures of Synechococcus cells in (a) the Seto Inland Sea, (b,c) the Bungo Channel, and (d) the Kuroshio region. FL2 and FL4: PUB and PEB (phycoerythrobilin) + PUB (phycourobilin) contents in Synechococcus cells, respectively 
high-PUB type of Synechococcus were higher in the Kuroshio region and the southern part of the Bungo Channel (Stns 15, 20, and 43, >10 × $10^{3}$ cells ml ${ }^{-1}$; Fig. 7a), where oceanic water intruded. High-PUBtype cells were not found at Stn 2. Overall, the distribution of the high-PUB type was quite similar to that of Prochlorococcus. In contrast to the high-PUB type of Synechococcus and Prochlorococcus, the low-PUBtype cells were higher in the Seto Inland Sea and the northern part of the Bungo Channel (Stns 2, 6, and 13, $>4 \times 10^{3}$ cells ml $^{-1}$; Fig. $7 \mathrm{~b}$ ) than those in the southern part of the Bungo Channel and the Kuroshio region (Stns 15, 20, and $43,<3 \times 10^{3}$ cells ml ${ }^{-1}$ ). Cell densities of both high- and low-PUB types of Synechococcus were also vertically uniform.

\section{Analysis of the fluorescence characteristics of Synechococcus cells}

The fluorescence spectra of sorted cells indicated that the Ex 495:545 was different within the high-PUBtype cells (Fig. 8). The high-PUB type in the Kuroshio region had a higher Ex 495:545 (1.9) than the same type of cells in the northern part of the Bungo Channel (0.9). We found a strong correlation between Ex 495:545 and FL2:FL4 ( $\mathrm{R}=0.878, \mathrm{n}=9$; Fig. 9).

A histogram of FL2:FL4 for each discriminated Synechococcus cell by dual laser flow cytometry indicated 3 peaks (Fig. 10). The FL2:FL4 for the low-PUB type
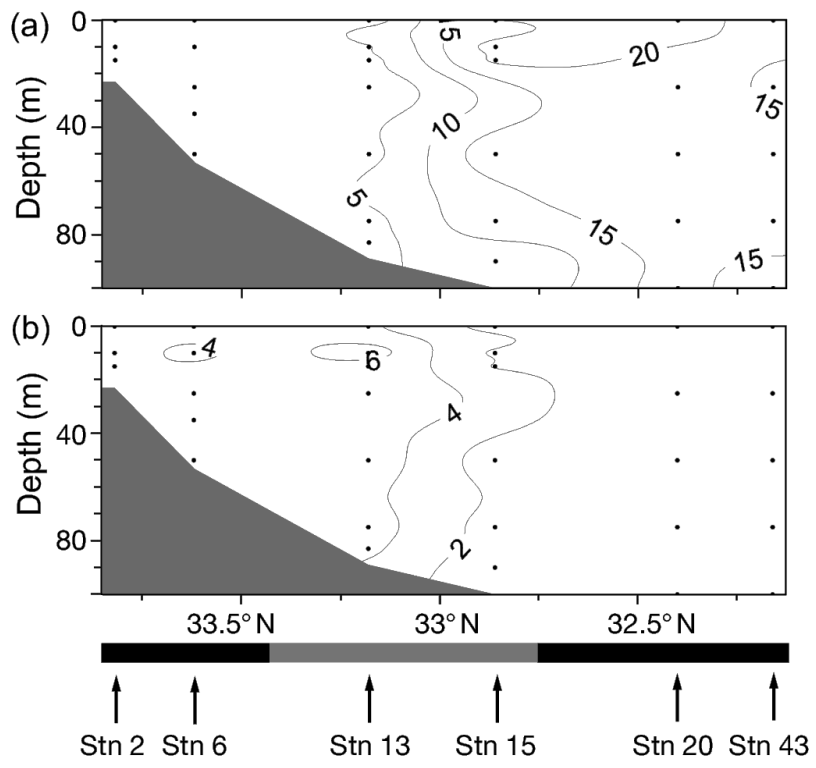

Fig. 7. Distribution of (a) high- and (b) low-PUB type of Synechococcus $\left(\times 10^{3}\right.$ cells $\left.\mathrm{ml}^{-1}\right)$ from the Seto Inland Sea to the Kuroshio region. Horizontal axis indicates north-south transect from Stns 2 to 43. Dots show the depths and stations of the samples collected by Niskin water samplers

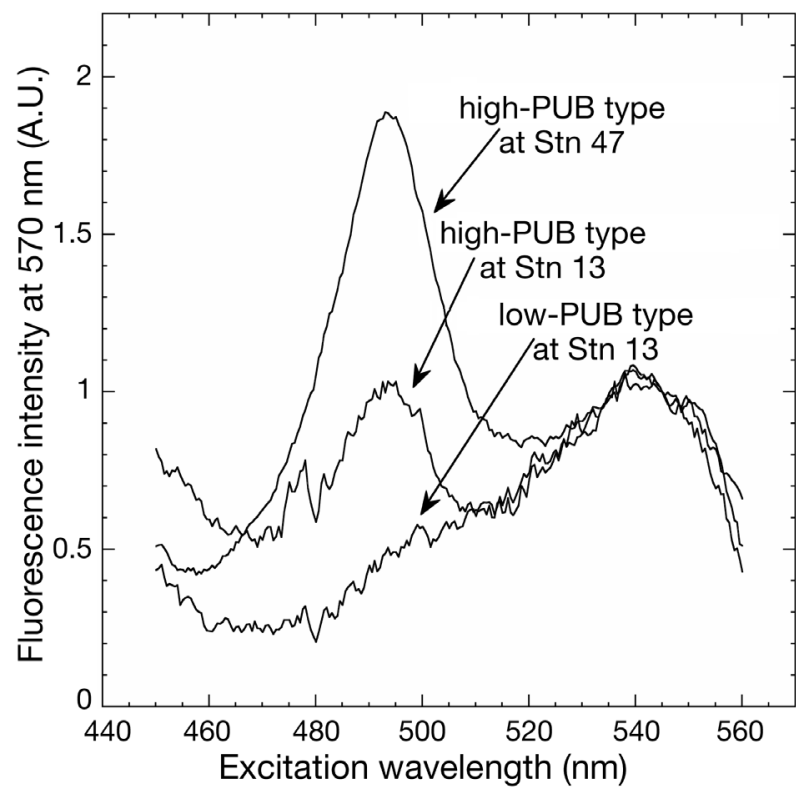

Fig. 8. Fluorescence excitation spectra of the sorted Synechococcus cells

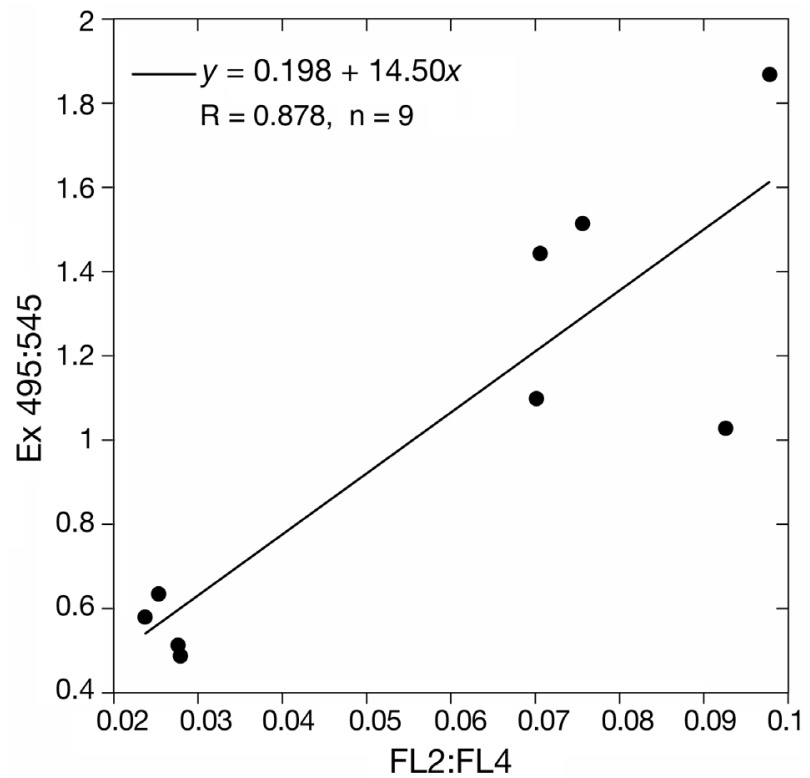

Fig. 9. Correlation between Ex 495:545 and FL2:FL4 of Synechococcus cells

ranged from 0.02 to 0.045 and seemed to form 1 peak. In contrast, there were 2 peaks in the distribution of FL2:FL4 within the high-PUB type: one ranged from 0.075 to 0.09 , and the other from 0.095 to 0.115 . In addition, these 2 sub-types were obtained at different stations. The high-PUB type with 0.075 to 0.09 of FL2:FL4 was from the Seto Inland Sea and the northern part of the Bungo Channel. The other type was from the Kuroshio region and the southern part of the Bungo Channel. These findings demonstrate that cells of the 


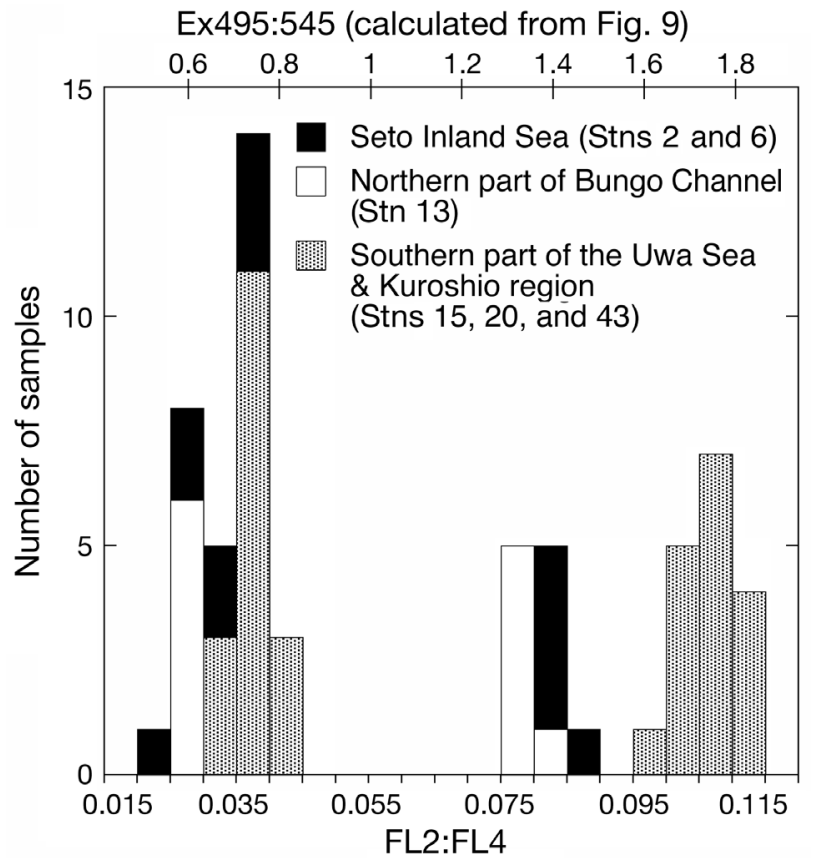

Fig. 10. Distributions of the FL2:FL4 ratio of Synechococcus cells collected from different stations

high-PUB type were different in the northern part of the Bungo Channel and the Kuroshio region, while the Ex 495:545 of the low-PUB type was almost identical.

Vertical distribution of Ex 495:545 for each type is shown in Fig. 11. Ex 495:545 for both high- and lowPUB types were almost the same with depth, although slightly higher values were found in the deeper layer for the high-PUB type at Stns 15, 20, and 43 and for the low-PUB type at Stns 20 and 43. At Stn 2, only the lowPUB type of Synechococcus cells was detected, as mentioned above (Fig. 7, Table 1). At Stns 6 and 13, we found the high-PUB type with 0.075 and 0.090 of
FL2:FL4, although the contribution was 5 and $28 \%$, respectively (Table 1). From Stns 13 to 15, the PE-pigment-type composition of Synechococcus drastically changed, probably due to the intrusion of oceanic water resulting from the Kyucho. At Stn 15, most Synechococcus cells were of the high-PUB type with 0.095 and 0.115 of FL2:FL4. Similar results were found at Stns 20 and 43. PE-pigment-type composition was similar at Stns 15, 20, and 43.

\section{DISCUSSION}

\section{Advection of prokaryotic picophytoplankton resulting from the Kyucho}

On 26 November, when the transect investigation was conducted, the oceanic water had intruded into Fukuura and Uchiumi, but had not yet reached Shimonada, Kitanada, and Shitaba (Fig. 2). The front of intruding water was located between Stns 13 and 15 (Fig. 1). Between Stns 13 and 15, a drastic shift in the prokaryotic picophytoplankton abundance was also observed (Figs. 5 \& 7 ). At Stns 15, 20, and 43, high abundances of Prochlorococcus $\left(>20 \times 10^{3}\right.$ cells ml $\left.{ }^{-1}\right)$ and the high-PUB type of Synechococcus $\left(>15 \times 10^{3}\right.$ cells ml $\left.{ }^{-1}\right)$ were detected. In contrast, the abundances of both Prochlorococcus and the high-PUB type of Synechococcus were low at Stns 2, 6, and 13 (Figs. 5 \& 7). Most Synechococcus cells were lowPUB type at Stns 2, 6, and 13 (Fig. 7, Table 1). These results clearly show that Prochlorococcus and the highPUB type of Synechococcus were advected as a result of a Kyucho from the Pacific Ocean to the Bungo Channel.

Generally, the distribution of Prochlorococcus is limited in the oligotrophic open ocean (Partensky et al. 1999). In the Mississippi River Plume and its adjacent

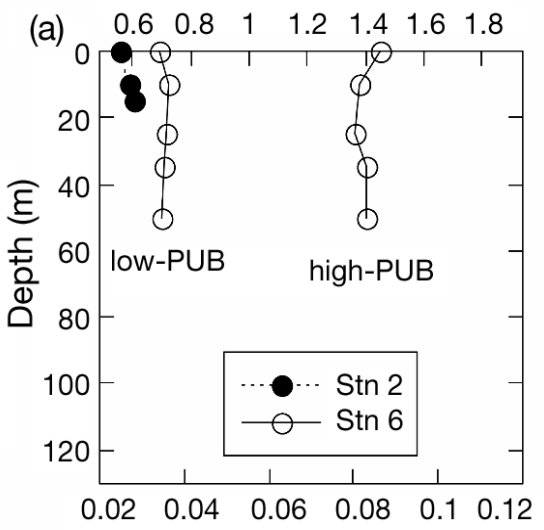

Ex495:545 (calculated from Fig. 9)
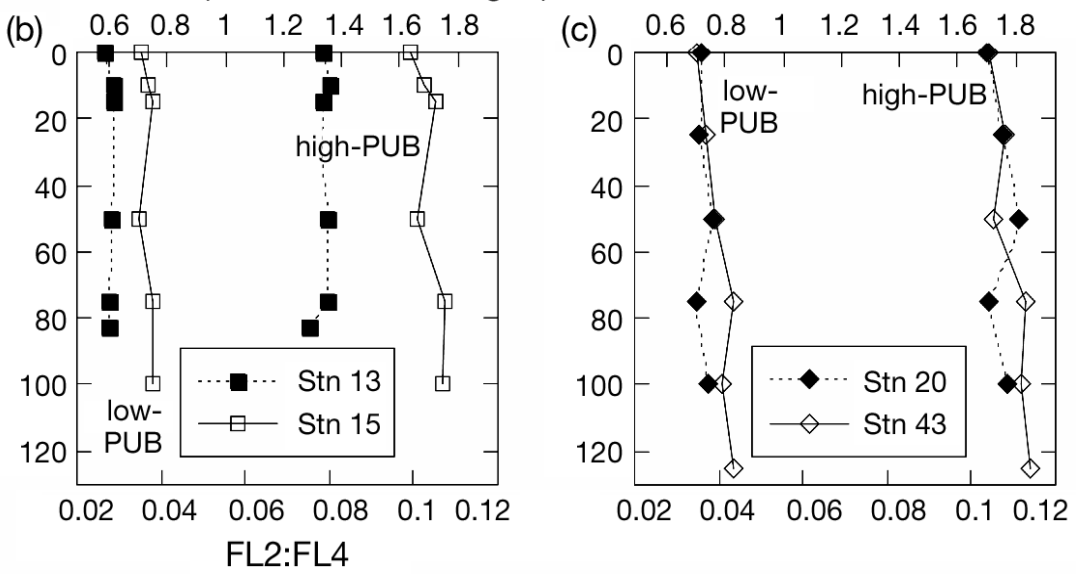

Fig. 11. Vertical distributions of the FL2:FL4 ratio of Synechococcus cells in (a) the Seto Inland Sea, (b) the Bungo Channel, and (c) the Kuroshio region 
Table 1. Shift in pigment type composition of Synechococcus from the Seto Inland Sea to the Kuroshio region. Values show means $( \pm$ SD). PUB: phycourobilin

\begin{tabular}{|c|c|c|c|c|}
\hline Stn & $\begin{array}{c}\text { Synechococcus } \\
\text { high-PUB type }\end{array}$ & $\begin{array}{l}\text { ell density } \\
\text { lls ml } \mathrm{ml}^{-1} \text { ) } \\
\text { low-PUB type }\end{array}$ & $\begin{array}{c}\text { Contribution of } \\
\text { high-PUB type } \\
(\%)\end{array}$ & $\mathrm{n}$ \\
\hline \multicolumn{5}{|c|}{ Seto Inland Sea } \\
\hline 2 & 0 & $4.3 \pm 0.4$ & 0 & 3 \\
\hline 6 & $0.2 \pm 0.0^{\mathrm{a}}$ & $4.1 \pm 0.4$ & $4.5 \pm 0.7$ & 4 \\
\hline \multicolumn{5}{|c|}{ Bungo Channel } \\
\hline 13 & $2.3 \pm 0.7^{a}$ & $5.9 \pm 1.8$ & $28.2 \pm 0.7$ & 4 \\
\hline 15 & $21.1 \pm 3.1^{\mathrm{b}}$ & $1.2 \pm 0.2$ & $94.7 \pm 0.8$ & 5 \\
\hline \multicolumn{5}{|c|}{ Kuroshio region } \\
\hline 20 & $18.8 \pm 2.3^{b}$ & $0.7 \pm 0.1$ & $96.3 \pm 0.7$ & 5 \\
\hline 43 & $15.3 \pm 3.3^{b}$ & $0.6 \pm 0.3$ & $96.0 \pm 1.2$ & 5 \\
\hline $\begin{array}{l}{ }^{\mathrm{a}} \mathrm{FL2} \\
{ }^{\mathrm{b}} \mathrm{FL} 2\end{array}$ & $\begin{array}{l}\text { to } 0.090 \\
\text { to } 0.115\end{array}$ & & & \\
\hline
\end{tabular}

waters, Prochlorococcus has been detected only in oceanic waters (Liu et al. 2004). In the East China Sea, no Prochlorococcus has been detected in coastal waters (Pan et al. 2005). However, in Suruga Bay (Shimada et al. 1995) and in Uchiumi Bay, located in the Bungo Channel (Katano et al. 2005), Prochlorococcus has been detected. Since the Kyucho also occurs in Suruga Bay (Inaba et al. 2003), the detected Prochlorococcus may have been transported from the open ocean.

Since Prochlorococcus was not detected throughout the year in Uchiumi Bay, the transported cells could not sustain its presence in the bay (Katano et al. 2005). The Prochlorococcus growth rate in coastal waters is probably lower than the grazing-loss rate. However, we still do not have enough information to speculate on the critical factor responsible for the disappearance of Prochlorococcus in coastal waters, since field observation data are still limited. Water temperature (Moore et al. 1995, Partensky et al. 1999), salinity, and turbidity (Pan et al. 2005), as well as trace metal concentrations (Mann et al. 2002), are considered possible reasons for the disappearance of Prochlorococcus in coastal waters. Prochlorococcus has evolved to be adapted to the environment of the open ocean (Rocap et al. 2003). For example, Prochlorococcus lost a nitrate reductase gene cluster, but still possesses iron-related genes that are missing in Synechococcus (Rocap et al. 2003). Thus, these cells can utilize the most prevalent nitrogen forms, i.e. ammonium and nitrite (Moore et al. 2002). The possession of iron-related genes may explain their dominance in the iron-limited equatorial Pacific (Campbell et al. 1997). In the course of evolution, Prochlorococcus probably lost essential genes for growth in coastal environments, and the crucial factor for its growth may differ according to each coastal environment.
The high-PUB type of Synechococcus was also advected as a result of the Kyucho, as reported above. In contrast to Prochlorococcus, the high-PUB type of Synechococcus actively grows in Uchiumi Bay (Katano et al. 2005, Katano \& Nakano 2006) and has been detected throughout the year (Katano et al. 2004). However, the fluorescence properties of high-PUB-type cells were different from those in the northern part of the Bungo Channel. The PE pigment type of Synechococcus seemed highly complex (Figs. $7 \&$ 10, Table 1). In the following section, we discuss the effect of the Kyucho on the PE-pigment-type composition and on the shift in the pigment-type composition from oceanic to coastal waters.

\section{PE-pigment-type composition of Synechococcus}

The classification of Synechococcus cells into 2 types has been conducted using different flow cytometers (Olson et al. 1988, 1990, Campbell \& Vaulot 1993, Campbell et al. 1998). Since the PUB:PEB ratio of Synechococcus cells continuously varies among strains (Wood et al. 1985, Waterbury et al. 1986, Toledo et al. 1999, Palenik 2001, Rocap et al. 2002, Fuller et al. 2003), it is difficult to simply classify isolated strains of Synechococcus into low- and high-PUB types. Thus, it is difficult to compare the ratios of PUB:PEB of the discriminated sub-populations of Synechococcus with flow cytometry in each environment. In the present study, we demonstrated the usefulness of determining the Ex 495:545 ratio for each type of cell, showing that dual laser flow cytometer combined with spectrofluorometry is a powerful tool for analyzing the PUB:PEB ratio of Synechococcus cells in marine environments.

The present study showed a shift in the PE-pigmenttype composition of Synechococcus from oceanic to coastal waters (Fig. 7, Table 1). Previous studies using spectrofluorometry also showed a difference in PE between oceanic and coastal waters (Lantoine \& Neveux 1997, Wood et al. 1998, Wood 1999). Similar to distinct Prochlorococcus ecotypes (adapted to high light and low light), which vertically partition the water column (Moore \& Chisholm 1999), different types of Synechococcus cells horizontally partition marine environments from oceanic to coastal waters. This is one explanation for the ubiquitous distribution of Synechococcus.

We found variation in the PUB:PEB ratio within the high-PUB type (Fig. 10). The low-PUB type found in the present study had almost the same Ex 495:545, and 
its distribution extended from the coastal to open ocean (Fig. 11). In contrast, the Ex 495:545 of the highPUB type in the Bungo Channel was obviously lower than that in the Kuroshio region (Figs. 10 \& 11). As far as we know, this is the first study to demonstrate that the shift in Synechococcus composition from oceanic to coastal waters was due, not only to the changes in the composition of the PE pigment type (the increase in the contribution of the low-PUB type to the total), but also to changes in the PUB:PEB in each PE pigment type (a decrease in the PUB:PEB ratio within the high-PUB type). Thus, the shift in the Synechococcus community composition from oceanic to coastal waters is highly complex.

The high-PUB type, with an Ex 495:545 of 1.6 to 1.8, was dominant at locations where most available light in the deeper layer was in the 450 to $500 \mathrm{~nm}$ range, corresponding to the peak wavelength for PUB absorbance (Fig. 4, Table 1). This is consistent with the spectrofluorometry study by Lantoine \& Neveux (1997), in which most PE had an Ex 495:545 of 1.6 to 1.9 in oligotrophic waters in the Atlantic Ocean. The high-PUB type seems to be well adapted to the spectral light quality of its habitat. In contrast, the low-PUB type was dominant when the available light was in the 480 to $580 \mathrm{~nm}$ range (Fig. 4, Table 1). Previous studies demonstrated that the content of PUB in Synechococcus cells is the result of adaptation for the efficient utilization of blue light in the open ocean (Wood 1985, Glover et al. 1986).

Generally, PE fluorescence of the cell increases with depth, as a result of photo-acclimation (Olson et al. 1990, Neveux et al. 1999). Olson et al. (1990) reported that PE fluorescence increased with depth by $>100$-fold in some cases. In addition, Lantoine \& Neveux (1997) found an increase in the PUB:PEB ratio of PE with depth at oligotrophic stations in the Atlantic Ocean. Therefore, the PUB:PEB ratio of the cells along the depth gradient is of interest. However, we could not find any trend in PE fluorescence or the FL2:FL4 of the cells with depth (Fig. 11). Furthermore, the cell densities of both Synechococcus and Prochlorococcus were also uniform in their vertical distributions (Figs. 5 \& 7). Water temperature and other physico-chemical factors indicate the vertical mixing of water in the euphotic layer (Fig. 3). Thus, in the present study, we could not discuss the vertical distribution of both high- and lowPUB types, or the PUB:PEB ratio of the cells in relation to the shift in light quality along the water depth gradient. Hence, we focused on the horizontal distribution of the high- and low-PUB types of Synechococcus in relation to the underwater light conditions.

The synthesis of PE by Synechococcus is genetically programmed and invariant within genotypes, even though some of the strains can synthesize 2 types of PE
(Wood et al. 1985, Ong \& Grazer 1991, Palenik 2001, Everroad et al. 2006). Wood et al. (1998) suggested that natural selection maintains the dominance of pigment types in certain regions: PUB-containing PE has an advantage in capturing the blue-light photons that are dominant in open oceans, but PUB-containing PE has never evolved in the green-light-dominated coastal waters. However, there was no significant difference in the growth rate between the low- and high-PUB types in the deeper layer (10 and $20 \mathrm{~m}$ depth) of the bay, where available light in the 480 to $570 \mathrm{~nm}$ range was dominant (Katano \& Nakano 2006). Even though PUB-containing PE has evolved in oceanic 'blue' waters, the high-PUB type has the capability of growing in the light environment of the bay.

The composition of the PE pigment in Uchiumi Bay, a body of water in the Bungo Channel, fluctuated significantly (Katano et al. 2004, Katano \& Nakano 2006). In 2001, there were 2 peaks of Synechococcus abundance in June and August (Katano et al. 2004). Analysis of the PE-pigment-type composition using single laser flow cytometry showed that the high-PUB type contributed $75 \%$ in June, but the contribution decreased to $40 \%$ in August (Katano et al. 2004). In 2003, the contribution of the high-PUB type estimated with dual laser flow cytometry increased from $38 \%$ in May to $75 \%$ in July (Katano \& Nakano 2006). In the present study, the Kyucho mainly advected the high-PUB type of Synechococcus cells (Fig. 7, Table 1). In the region of origin of the Kyucho (Kuroshio), the high-PUB type probably predominates in the Synechococcus community. Generally, Kyucho events occur from June to October, when the water column is thermally stratified (Takeoka et al. 2000) and there is no intrusion of coastal water from the Seto Inland Sea, where the low-PUB type was dominant. Thus, the composition of the pigment type of Synechococcus in the Bungo Channel during the thermally stratified period may be highly affected by the Kyucho rather than by the light environment.

The co-occurrence of at least $2 \mathrm{PE}$ pigment types in Synechococcus cells is frequently found in coastal waters (Wood et al. 1985, Olson et al. 1990, Campbell et al. 1998, Liu et al. 1998, 2004, Collier \& Palenik 2003, Jiao et al. 2005). In such areas, where co-occurrence of the 2 types has been observed, there are physical disturbances, such as monsoons in the Arabian Sea (Campbell et al. 1998, Liu et al. 1998), upwelling off California (Collier \& Palenik 2003), and the Kuroshio Current in the East China Sea (Jiao et al. 2005). Unfortunately, there is insufficient information about the underwater light environment and physical processes combining oceanic and coastal waters. However, it is possible that the co-occurrence in coastal waters is related to both the underwater light environment and the physical disturbance. 
Some of the strains possess the ability to change the PUB:PEB ratio depending on the light environment (Palenik 2001, Everroad et al. 2006). However, the distribution of such cells has not been evaluated in a marine environment. In addition, few studies have evaluated the ratio of PUB:PEB in natural Synechococcus, and the ecological meaning of the high variation of PUB:PEB among Synechococcus strains has not been clarified. Thus, even if there were chromatically adapted Synechococcus cells, it would still be meaningful to evaluate the PUB:PEB ratio of each type of Synechococcus cell in a given light environment.

There are 2 mechanisms to explain the shift in PUB:PEB in bulk PE from oceanic to coastal areas, as already reported (Lantoine \& Neveux 1997, Wood et al. 1998, Neveux et al. 1999): one is the shift in the community composition on a genetic level and the other is chromatic adaptation. In the present study, we demonstrated the co-occurrence of at least 2 different PE pigment types in the Kuroshio region and the Seto Inland Sea (Table 1). Here, a shift in the PE-pigment-type composition from oceanic to coastal waters was observed, as mentioned above. This suggests the existence of cells that do not have a chromatic adaptation ability. Olson et al. (1990) found 3 distinct populations with different cellular PUB:PEB ratios in a coastal sample. It is possible that these 3 populations corresponded to the 1 low- and 2 high-PUB types of Synechococcus cells found in the present study. If so, the cells lacking chromatic adaptation ability may cooccur in the same water body.

On the contrary, Everroad et al. (2006) pointed out the ubiquitous distribution of chromatic adapters in the oceans. It is also possible that high-PUB-type cells that advected from the Pacific Ocean adapted chromatically to the light environment of the Bungo Channel or the Seto Inland Sea, although some of the individual cells did not have such an ability (Table 1). In such a case, the time may not have been sufficient for the high-PUB type to adapt chromatically, since our sampling was conducted just after the Kyucho occurrence (Fig. 2). To clarify such quandaries, other techniques should be used.

Synechococcus is divided into at least 10 clades based on 16S rRNA gene sequencing (Fuller et al. 2003). In at least 3 of these clades, strains differing in $\mathrm{PE}$ pigment composition were found within a single clade. The fact that differences in pigment composition were observed in $>1$ clade suggests differences in physiological traits, such as nitrogen requirements, motility, or halotolerance other than photophysiology within cells with similar or identical PUB:PEB ratios. Fuller et al. (2003) expected that Synechococcus lineages define a more complicated suite of niches and underlying physiologies. As we demonstrated in the present study, the shift in the composition of the PE pigment type from oceanic to coastal waters was highly complex. Other traits are presumably also related to the ubiquitous distribution of Synechococcus in marine environments. In addition to the PUB:PEB ratio, the genetic variation of Synechococcus should be examined along the environmental gradient from open to coastal waters to better understand this important contributor to primary production in the oceans.

Acknowledgements. We are grateful to Profs Y. Hayami and T. Kohama for their help in analyzing nutrient concentrations, and to laboratory members of Coastal Oceanography, CMES, Ehime University, for their help in sampling and analyzing nutrient concentrations. Thanks also to Prof. A. Turner for his correction of the English and constructive comments on the manuscript. This study was partly supported by a Grant-inAid for Scientific Research No. 16201004, JSPS.

\section{LITERATURE CITED}

Agawin NSR, Duarte CM, Agustí S (2000) Nutrient and temperature control of the contribution of picoplankton to phytoplankton biomass and production. Limnol Oceanogr 45:591-600

Akiyama H, Saitoh S (1993) The Kyucho in Sukumo Bay induced by Kuroshio warm filament intrusion. J Oceanogr 49:667-682

Alberte RS, Wood AM, Kursar TA, Guillard RRL (1984) Novel phycoerythrins in marine Synechococcus spp. Plant Physiol 75:732-739

Bell T, Kalff J (2001) The contribution of picophytoplankton in marine and freshwater systems of different trophic status and depth. Limnol Oceanogr 46:1243-1248

Campbell L, Vaulot D (1993) Photosynthetic picoplankton community structure in the subtropical North Pacific Ocean near Hawaii (Station ALOHA). Deep-Sea Res 40: 2043-2060

Campbell L, Liu H, Nolla HA, Vaulot D (1997) Annual variability of phytoplankton and bacteria in the subtropical North Pacific Ocean at Station ALOHA during the 1991-1994 ENSO event. Deep-Sea Res 44:167-192

Campbell L, Landry MR, Constantinou J, Nolla HA, Brown SL, Liu H, Caron DA (1998) Response of microbial community structure to environmental forcing in the Arabian Sea. Deep-Sea Res 45:2301-2325

Collier JL, Palenik B (2003) Phycoerythrin-containing picoplankton in the Southern California Bight. Deep-Sea Res 50:2405-2422

Everroad C, Six C, Partensky F, Thomas JC, Holtzendorff J, Wood AM (2006) Biochemical bases of type IV chromatic adaptation in marine Synechococccus spp. J Bacteriol 188: 3345-3356

Fuller NJ, Marie D, Partensky F, Vaulot D, Post AF, Scanlan DJ (2003) Clade-specific 16S ribosomal DNA oligonucleotides reveal the predominance of a single marine Synechococcus clade throughout a stratified water column in the Red Sea. Appl Environ Microbiol 69:2430-2443

Glover HE, Keller MD, Guillard RRL (1986) Light quality and oceanic ultraphytoplankters. Nature 319:142-143

Inaba H, Yasuda K, Kawabata K, Katsumata T (2003) Kyucho in Suruga Bay in early March 1992. Oceanogr Jpn 12: 59-67 (in Japanese with English abstract) 
Jeffrey SW, Welschmeyer NA (1997) Spectrophotometric and fluorometric equations in common use in oceanography. In: Jeffrey SW, Mantoura RFC, Wright SW (eds) Phytoplankton pigments in oceanography. UNESCO Publishing, Paris, p 597-615

Jiao N, Yang Y, Hong N, Ma Y, Harada S, Koshikawa H, Watanabe M (2005) Dynamics of autotrophic picoplankton and heterotrophic bacteria in the East China Sea. Cont Shelf Res 25:1265-1279

Katano T, Nakano S (2006) Growth rates of Synechococcus types with different phycoerythrin composition estimated by dual-laser flow cytometry in relationship to the light environment in the Uwa Sea. J Sea Res 55:182-190

Katano T, Hirose M, Nakano S (2004) Discrimination of two phycoerythrin-pigment types of Synechococcus and their seasonal succession in the Uwa Sea. Microbes Environ 19: $7-12$

Katano T, Kaneda A, Takeoka H, Nakano S (2005) Seasonal changes in the abundance and composition of picophytoplankton in relation to the occurrence of Kyucho and bottom intrusion in Uchiumi Bay, Japan. Mar Ecol Prog Ser 298:59-67

Lantoine F, Neveux J (1997) Spatial and seasonal variations in abundance and spectral characteristics of phycoerythrins in the tropical northeastern Atlantic Ocean. Deep-Sea Res 44:223-246

Li WKW (1995) Composition of ultraphytoplankton in the central North Atlantic. Mar Ecol Prog Ser 122:1-8

Liu H, Campbell L, Landry MR, Nolla HA, Brown SL, Constantinou J (1998) Prochlorococcus and Synechococcus growth rates and contributions to production in the Arabian Sea during the 1995 Southwest and Northeast Monsoons. Deep-Sea Res 45:2327-2352

Liu H, Dagg M, Campbell L, Urban-Rich J (2004) Picophytoplankton and bacterioplankton in the Mississippi River plume and its adjacent waters. Estuaries 27:147-156

Mann EL, Ahlgren N, Moffett JW, Chisholm SW (2002) Copper toxicity and cyanobacteria ecology in the Sargasso Sea. Limnol Oceanogr 47:976-988

Moore LR, Chisholm SW (1999) Photophysiology of the marine cyanobacterium Prochlorococcus: ecotypic differences among cultured isolates. Limnol Oceanogr 44: $628-638$

Moore LR, Goericke R, Chisholm SW (1995) Comparative physiology of Synechococcus and Prochlorococcus: influence of light and temperature on growth, pigments, fluorescence and absorptive properties. Mar Ecol Prog Ser 116:259-275

Moore LR, Post AF, Rocap G, Chisholm SW (2002) Utilization of different nitrogen sources by the marine cyanobacteria Prochlorococcus and Synechococcus. Limnol Oceanogr 47:989-996

Neveux J, Lantoine F, Vaulot D, Marie D, Blanchot J (1999) Phycoerythrins in the southern tropical and equatorial Pacific Ocean: evidence for new cyanobacterial types. J Geophys Res C 104:3311-3321

Olson RJ, Chisholm SW, Zettler ER, Armbrust EV (1988) Analysis of Synechococcus pigment types in the sea using single and dual beam flow cytometry. Deep-Sea Res 35: 425-440

Olson RJ, Chisholm SW, Zettler ER, Armbrust EV (1990) Pigments, size, and distribution of Synechococcus in the North Atlantic and Pacific Oceans. Limnol Oceanogr 35: $45-58$

Editorial responsibility: William Li,

Dartmouth, Nova Scotia, Canada
Olson RJ, Zettler ER, DuRand MD (1993) Phytoplankton analysis using flow cytometry. In: Kemp PF, Sherr BF, Sherr EB, Cole JJ (eds) Handbook of methods in aquatic microbial ecology. Lewis Publishers, Boca Raton, FL, p 175-186

Ong LJ, Glazer AN (1991) Phycoerythrins of marine unicellular cyanobacteria. I. Bilin types and locations and energy transfer pathways in Synechococcus spp. phycoerythrins. J Biol Chem 266:9515-9527

Ong LJ, Glazer AN, Waterbury JB (1984) An usual phycoerythrin from a marine cyanobacterium. Science 224:80-82

Palenik B (2001) Chromatic adaptation in marine Synechococcus strains. Appl Environ Microbiol 67:991-994

Pan LA, Zhang LH, Zhang J, Gasol JM, Chao M (2005) Onboard flow cytometric observation of picoplankton community structure in the East China Sea during the fall of different years. FEMS Microbiol Ecol 52:243-253

Partensky F, Hess WR, Vaulot D (1999) Prochlorococcus, a marine photosynthetic prokaryote of global significance. Microbiol Mol Biol Rev 63:106-127

Rocap G, Distel DL, Waterbury JB, Chisholm SW (2002) Resolution of Prochlorococcus and Synechococcus ecotypes by using 16S-23S ribosomal DNA internal transcribed sequences. Appl Environ Microbiol 68:1180-1191

Rocap G, Larimer FW, Lamerdin J, Malfatti S and 20 others (2003) Genome divergence in two Prochlorococcus ecotypes reflects oceanic niche differentiation. Nature 424 : 1042-1047

Shimada A, Nishijima M, Maruyama T (1995) Seasonal appearance of Prochlorococcus in Suruga Bay, Japan in 1992-1993. J Oceanogr 51:289-300

Takeoka H, Akiyama H, Kikuchi T (1993) The Kyucho in the Bungo channel, Japan-periodic intrusion of oceanic warm water. J Oceanogr 49:369-382

Takeoka H, Koizumi Y, Kaneda A (2000) Year-to-year variation of a Kyucho and a bottom intrusion in the Bungo Channel, Japan. In: Yanagi T (ed) Interactions between estuaries, coastal seas and shelf seas. Terra Scientific Publishing, Tokyo, p 197-215

Toledo G, Palenik B, Brahamsha B (1999) Swimming marine Synechococcus strains with widely different photosynthetic pigment ratios form a monophyletic group. Appl Environ Microbiol 65:5247-5251

Waterbury JB, Watson SW, Valois FW, Franks DG (1986) Biological and ecological characterization of the marine unicellular cyanobacterium Synechococcus. Can Bull Fish Aquat Sci 214:71-120

Wood AM (1985) Adaptation of photosynthetic apparatus of marine ultraphytoplankton to natural light fields. Nature 316:253-255

Wood AM, Horan PK, Muirhead K, Phinney DA, Yentsch CM, Waterbury JB (1985) Discrimination between types of pigments in marine Synechococcus spp. by scanning spectroscopy, epifluorescence microscopy, and flow cytometry. Limnol Oceanogr 30:1303-1315

Wood AM, Phinney DA, Yentsch CS (1998) Water column transparency and the distribution of spectrally distinct forms of phycoerythrin containing organisms. Mar Ecol Prog Ser 162:25-31

Wood AM, Lipsen M, Coble P (1999) Fluorescence-based characterization of phycoerythrin-containing cyanobacterial communities in the Arabian Sea during the Northeast and early Southwest Monsoon (1994-1995). Deep-Sea Res 46:1769-1790

Submitted: January 11, 2006; Accepted: October 4, 2006

Proofs received from author(s): January 13, 2007 